\title{
The Historical Roots of the North-South Dynamic in Biodiversity Conservation and its Imprint on the Convention on Biological Diversity
}

Pre-proofs version - Chapter published in: Razzaque, J. \& Morgera, E. (2016)

Biodiversity and Nature Protection Law (Edward Elgar)

Dr Andreas Kotsakis

Oxford Brookes University

ABSTRACT

The concept of biodiversity has been historically constituted by a series of North-South disputes over its meaning and application. The following chapter places the entry of biodiversity into international environmental law within its historical and political context and outlines the exposure and collisions with other discourses and rationalities that occurred around the adoption and early operation of the Convention on Biological Diversity (CBD). While the concept of biodiversity emerged within Northern conservation practice, the reality of the South as the holder of the remaining biodiversity reserves has forced a continued and often contentious engagement with the political economy of Southern development. The chapter identifies a troubling orientalist pattern in this engagement that repeats throughout the decades: the North always proposes first and the South is expected to reacts and adapt.

KEYWORDS: environmental history, biodiversity, overpopulation, North-South relations, development

\section{TABLE OF CONTENTS:}

Introduction

* Malthus, Overpopulation and Limits: Steps towards a Political Economy of Biodiversity .... 3

* The 'Tropics' and the Shift in Negotiating Basis for the Convention on Biological Diversity7 


\section{INTRODUCTION}

Biodiversity has been a difficult concept to define with clarity, and biological diversity has been an environmental public good difficult to measure with precision and protect with confidence against multiple threats, such as habitat loss, pollution, climate change and overharvesting.

This has been largely attributed to the pluralism of the term itself ${ }_{1}$, constituting both a normative concept that sets out the environmental and other values to be pursued in conservation2, as well as a scientific description of the natural world structured across the three tiers of genetic, species and ecosystem variabilityз. In simple terms, it constitutes a method for both knowing and valuing nature. The two understandings are often interlinked 4 , and often used to strongly advocate a holistic practice of biodiversity conservation rooted in ecological ethics and unashamedly valueladen assessments of a rapidly evolving environmental crisis 5. The early proponents of biodiversity regarded themselves as belonging to a 'mission-oriented' discipline6. Other conservationists eventually grew frustrated with the all-encompassing aspect of the idea as well as

\footnotetext{
1 A common theme, see generally Sahotra Sarkar, Biodiversity and Environmental Philosophy: An Introduction (Cambridge University Press 2005) Timothy J. Farnham, Saving Nature's Legacy : Origins of The Idea of Biological Diversity (Yale University Press 2007) Thomas E. Lovejoy, 'Biodiversity: What Is it?' in Marjorie L. Reaka-Kudla, Don E. Wilson and Edward O. Wilson (eds), Biodiversity II: Understanding and Protecting Our Biological Resources (Joseph Henry Press 1996)

2 J. Baird Callicott, Larry B. Crowder and Karen Mumford, ‘Current Normative Concepts in Conservation’ (1999) 13 Conservation Biology 22

3 Farnham at 23-26

4 Most prominently and urgently in the work of Edward O. Wilson, one of the most prominent proponents of the term. For an overview see Edward O. Wilson, The Diversity of Life (Penguin 2001)

5 In contrast to more positivist paradigms of conservation outlined in Paul Roebuck and Paul Phifer, 'The Persistence of Positivism in Conservation Biology' (1999) 13 Conservation Biology 444

6 For an early statement of this approach see Michael E. Soule and Bruce A. Wilcox (eds), Conservation Biology: An Evolutionary-Ecological Perspective (Sinauer 1980), at 1.
} 
the failure to distinguish or prioritize between the three levels, dismissing biodiversity as essentially meaningless7.

This is quite clearly a snapshot of a larger debate occurring for decades in Northern environmental discourse essentially between conservationists and policy makers regarding the most effective conservation methods. However, the framing of the problem of biodiversity loss inherently implies a transboundary, if not global, perspective. Hence, the entry of biodiversity into international environmental law was inevitable.

The following chapter seeks to place this entry of biodiversity within a historical and political context and to outline the exposure and collisions with other discourses and rationalities that occurred around the adoption and early operation of the Convention on Biological Diversity (CBD). By adopting this historical perspective, the chapter shows that the initial generic problematisation of conservation practices in the North was swiftly enveloped within the broader problematisation of the South itself. Since then, the North-South dynamic in biodiversity has followed a pattern whereby the South is always responding to Northern proposals.

\section{Malthus, Overpopulation and Limits: Steps towards a Political ECONOMY OF BIODIVERSITY}

In the 'bible of biodiversity's, the proceedings of a symposium of the US National Academy of Sciences held in 1986 where the term was first preconsolidated, a neo-Malthusian perspective had emerged as central to the discussion of the causes of biodiversity loss. Habitat erosion or

\footnotetext{
7 On such a rejection from a practitioners perspective see R.A. Lautenschlager, 'Biodiversity is Dead' (1997) 25 Wildlife Society Bulletin 679; Sarkar also makes similar points regarding the absurdity of biodiversity meaning everything in biology

8 The characterisation is indicative of the continuing importance of the edited collection and borrowed from Michael Flitner, 'Biodiversity: Of Local Commons and Global Commodities' in Michael Goldman (ed), Privatizing Nature: Political Struggles for the Global Commons (Pluto Press 1998) at 145.

9 Edward O. Wilson (ed), BioDiversity (National Academy Press 1988)
} 
destruction due to the expansion of human population and its attendant activities was identified as the primary cause for the decline of biodiversity 10. By consequence, halting population growth was the key 'dramatic step' to be taken in order to arrest the rising rates of extinction and extirpation, as well as severe degradation of ecosystem services11. This chapter on the causes and consequences of biodiversity loss was written by Paul Ehrlich, at the time one of the main proponents of population control as environmental policy. Some historical background will explain why the incorporation of this line of thinking profoundly affected the North-South dynamic in biodiversity discourse.

The general prediction that human society is bound to collapse under the pressure of producing enough resources to sustain its ever-growing population of course can be traced to the theory of population of Thomas Malthus. We can now interpret Malthus as opposing the Enlightenment view of continuing social, political and economic progress on what we would call ecological grounds12. Due to the limits of the land, any increases in agricultural production will inevitably fail to keep pace with the additional population growth that comes from such progress, further exacerbating poverty, hunger and disease 13. Malthusian demography also possesses a strong normative element. He argued against the passing of Poor laws of England 14 on the basis that any help would facilitate an increase in the already unsustainable (as evidenced by their plight) population of the 'lower social orders' and thus exacerbate the difficulty of agricultural production to keep pace with population growth. According to this view, in reality these laws would only prolong their suffering by removing the preventive and positive checks on their numbers 15 , to the detriment of society as a whole.

\footnotetext{
10 Paul Ehrlich, 'The Loss of Diversity: Causes and Consequences' in Edward O. Wilson (ed), Biodiversity (National Academy Press 1988), at 21.

11 Ibid at 25.

12 John Barry, Environment and Social Theory (2nd edn, Routledge 2007) at 61-62.

13 Thomas R. Malthus, An Essay on the Principle of Population and a Summary View of the Principle of Population (Penguin 1982)

14 Ibid at 93-103.

15 Ibid at 89-91.
} 
The rediscovery of Malthusian thought in $20^{\text {th }}$ century environmental thought proceeded by way of William Vogt's Road to Survival, which expanded the narrow Malthusian argument's focus on agricultural production towards the exploitation of scarce natural resources more generally, calling the USA a 'self-cannibal' for drawing too much from its own earth16. Malthus subsequently gained renewed popular acceptance through Paul Ehrlich's overpopulation thesis17 of the late 1960s, which predicted famine, disease and eventual societal collapse due to the pressure of 'too many people' on Earth. The combination of Malthusian predictions and environmental thought reached its high point in the early 1970s with the influential limits to growth' thesis18, the first major application of computer modelling in the service of environmental predictions. The limits to growth approach argued for the reduction of human population growth, the abandonment of the pursuit of continuous economic growth and the move towards a 'steady-state economy' as solutions for preventing global ecosystemic collapse. The next major step was the inveigling within the emerging concept of biodiversity, as highlighted in the beginning of this section.

One of the many criticisms against this re-emergence of Malthusian demographics - and the one most relevant for this chapter's examination of biodiversity - was precisely its rather crude attempt to recast North-South relations. By substituting 'poor nations' for Malthus' 'lower social classes', reactionary - masquerading as realist or pragmatic - arguments against development assistance and even food aid were made, on the basis that such efforts would prevent the necessary reduction in human population to avert global ecological catastrophe 19. Such arguments led to accusations of barbarism 20.

\footnotetext{
16 William Vogt, Road to survival (Gollancz 1949) at 112.

17 The first best-selling book popularising the term was Paul R. Ehrlich, The Population Bomb (Pan Books 1971).

18 Donella H. Meadows and others, The Limits to Growth : a Report for the Club of Rome's Project on the Predicament of Mankind (Universe Books 1972).

19 Most controversially articulated in Garret Hardin's 'lifeboat ethics' metaphor.

20 Barry Commoner, The Closing Circle : Confronting the Environmental Crisis (Cape 1972)
} 
Making what is presented as a factual and neutral argument that 'overpopulation' is the primary cause of environmental problems has very clear normative implications for the South, given the difference with the low rates of population growth in the industrialised North. It not only depicts the environmental impact of the South as the primary challenge, conveniently obfuscating the role of overconsumption and the histories of colonialism and imperialism that produced the loss of habitat, ecosystem degradation, poverty, hunger and disease claimed as the indicators of 'too many people'. It also, and perhaps more worryingly, channels Malthus's distaste and negativity towards the poor, to produce a racist and neo-colonial image of the South as a mass of people, plagued by poverty, famine and disease, threatening to engulf the whole planet21. Such perceptions were doubly unfortunate during the 1970s, when the call for a 'New International Economic Order' and an increased role for the South in the international system was being articulated. Unsurprisingly, the method of framing global environmental problems using Malthusian limits was heavily contested by the South acting as a collective and did not bode well for the legitimacy of the at the time nascent global environmental governance 22.

Yet the emphasis on population by way of habitat loss found its way into the conceptualisation of biodiversity. This emphasis exposed biodiversity to larger debates regarding fairness and equity in international relations and the historical responsibility for the current environmental crisis, which are profoundly affected by the claim that overpopulation trumps overconsumption as the source of environmental problems. These debates escape the narrow confines of Northern environmentalism and are located within the broader 'politics of the Earth' ${ }_{23 .}$

\footnotetext{
21 See for example Paul R. Ehrlich, Anne H. Ehrlich and John P. Holdren, Ecoscience: Population, Resources, Environment (W.H. Freeman and Co 1972). Note however that Ehrlich was always careful to attempt to balance the political implications of these arguments due to critique. For example, he mentions the need to curtail 'the environmental impact of the rich to permit the poor a chance for reasonable development' in Ehrlich, p. 26 and the fact 'the cornerstone of a rational programme should be a great reduction in the growth of throughput of energy and materials in the rich countries in Ibid, p. 956. However, these statements are largely drowned by the overall clear emphasis on overpopulation as the primary cause of environmental problems.

22 Adil Najam, 'Developing Countries and Global Environmental Governance: From Contestation to Participation to Engagement' (2005) 5 International Environmental Agreements 303, at 307-309.

23 John S. Dryzek, The Politics of the Earth: Environmental Discourses (3rd edn, Oxford University Press 2013)
} 
This exposure produced an interesting epistemological effect. These controversial debates required knowledge of the history and political economy of the South itself; and its absence might explain some of the statements of conservationists on the basis of naivety, as opposed to commitment to certain reactionary politics. But the concept was no longer describing and organizing the natural world, but also the South itself; hence the need for the different forms of knowledge and the realisation that a certain political economy of the South had to constitute part of how biodiversity was to be understood. Such a process would not be devoid of its own quite considerable and long-standing intellectual baggage.

\section{The ‘Tropics' AND THE SHIFT In Negotiating BASIS FOR THE}

\section{Convention on Biological Diversity}

The focus on the South as the place where biodiversity is most endangered due to the encroachment of human population was not only supported by neo-Malthusian conceptions of the South, but also by the scientific recognition that the rainforests actually hold the majority of the world's remaining biodiversity reserves 24 . Biodiversity signalled the capacity of biological knowledge to provide scientific evidence - in the shape of estimates of numbers of various microorganisms, plants, insects and animals being under threat - of the global environmental value and importance of Southern ecosystems. Although the assumptions of the overpopulation thesis could be readily questioned, the importance of rainforests for the functioning of the global Earth system could not be challenged on a similar political economic basis.

The emphasis on 'tropical countries' and the 'tropics' 25 in part reflected long-standing research interests, expertise and collaborations, as well as the ecological awareness, of the biologists and

\footnotetext{
24 Edward O. Wilson, 'The Current State of Biological Diversity' in Edward O. Wilson (ed), BioDiversity (National Academy Press 1988), at 8-10.

25 For a critique of this focus see David Takacs, The Idea of Biodiversity: Philosophies of Paradise (The John Hopkins University Press 1996), at 288-300, where Daniel H. Janzen's influential work and commitment to depicting Costa Rica as a 'Canaan for biodiversity' is outlined in highly ambivalent terms.
} 
conservationists heavily involved in the introduction of the concept of biodiversity. The research programme of conservation biology, from within which the idea of biodiversity first emerged, outlined its own 'ecological principles of conservation' in a series of chapters included in a major 1980 edited collection; all principles were drawn from research on the conservation of tropical plants and animals26, reflecting the belief that 'tropical habitats are more sensitive, less resilient and in greater danger of complete destruction'27. More recently, the identification of specific 'biodiversity hotspots' 28 , i.e. 'areas featuring exceptional concentrations of endemic species and experiencing exceptional loss of habitat' 29 , was presented as a new strategy for prioritising biodiversity conservation efforts, but also further confirmed the Southern focus of biodiversity discourse. Aside from the Mediterranean basin and the 'California floristic Province', all other hotspots were located in the South.

This scientific understanding and ecological interest was combined with (if not overwhelmed by) neo-Malthusian demography to establish an image of the South as the site where the struggle to prevent the loss of biodiversity would take place. The South possessed both the largest remaining reserves of biodiversity (viewed as a natural resource) as well as the largest segment of human population and rate of population growth, considered the primary causes for the pressure and reduction of these reserves. If the sixth major extinction is to be slowed down or averted, this would have to be accomplished in the South.

Biodiversity conservation thus attached crucial environmental value to areas, such as the rainforests, previously considered a burden and a sign of 'underdevelopment', albeit with the provision of these areas containing the requisite amount of high diversity. However, this particular conception of the South as being both the cause and solution to the environmental problem of biodiversity loss also construed large areas of tropical habitats and rainforests, as well

\footnotetext{
26 See the whole Part. I, p.9-92 in Soule and Wilcox

27 Ibid, at xi.

28 Norman Myers and others, 'Biodiversity Hotspots' (2000) 43 Nature 853

29 Ibid at 853 .
} 
as the biological resources they contain, as an economic opportunity. In a context of contestation and hesitant participation in global environmental regimes by the South in the 1980s, it is no surprise that biodiversity's potential as negotiating leverage was first identified; a test for the North's true (in the sense of not masking the continuation of interventionist imperialist and colonial practices) commitment to environment assessed by its willingness to pay in order address this newly materialised environmental problem. In many ways, biodiversity appeared to certain Southern developmental states as a resource akin to oil 30 :

'[...] Their possession of the mainly untapped resource potential of species biodiversity within their territories presents them with an unrivalled opportunity to finally to gain what may euphemistically be called lost development ground [...] Access to these resources should therefore be jealously guarded, especially from would be competitors who lack such species biodiversity within their own jurisdictions' 31.

Even the idea of forming an oligopoly, a cartel of 'megabiodiverse' countries to secure royalty payments, the option value and other economic returns on the areas of high biodiversity that would be protected and thus remain 'undeveloped' has been proposed in the context of this line of thought32.

The existence of this leverage became progressively apparent from the very first few hesitant steps towards an international biodiversity treaty taking place at the UNEP negotiating table from 1988 onwards33. Given how the stakes were raised in terms of the fundamental role of biodiversity held by the South for human survival itself, it was logical to expect significant

\footnotetext{
30 The 'official stance' and some of these negotiating tactics are astutely summarised in R. Jayakumar Nayar and David Mohan Ong, 'Developing Countries, 'Development' and the Conservation of Biological Diversity' in Catherine Redgwell and Michael Bowman (eds), International Law and the Conservation of Biological Diversity (Kluwer Law International 1995), at 236-241. 31 Ibid 237

32 Joseph Henry Vogel, 'From the 'Tragedy of the Commons' to the 'Tragedy of the Commonplace': Analysis and Synthesis through the Lens of Economic Theory' in Charles R. McManis (ed), Biodiversity and the Law : Intellectual Property, Biotechnology \& Traditional Knowledge (Earthscan 2007).

33 This negotiation commenced following UNEP/GC/Res 14/26, (1987). The actual drafting phase, incorporating the shifts outlined in this section of the chapter, began following UNEP/GC/Res 15/34 (1989).
} 
additional funding for relevant conservation initiatives, and the question of funding levels and arrangements of the financial mechanism of the proposed treaty dominated early discussions 34 . This was the specific manifestation of the test of Northern commitment to the discourse of biodiversity discussed above, but also served as a path for establishing the legitimacy of the emerging global biodiversity regime as a multilateral endeavour. In addition, the Brundtland Report35 included a 'priority proposal' to 'investigate the prospect of agreeing to a 'species convention', similar in spirit and scope to the Law of the Sea Treaty'36. This 'species convention' would be a type of framework treaty that rationalises and codifies customary law and principles regarding nature conservation, but also extend to unifying disparate existing international treaty regimes37; under a legal approach to biodiversity as common heritage that was based on the biosphere-influenced approach of living resource conservation enshrined in the earlier World Conservation Strategy 38.

Given the leverage, this was not the kind of framework treaty that was eventually signed, since the CBD text confirmed the principle of state sovereignty over biological resources39, and by extension over any crucial biodiversity hotspots. Attribution of common heritage to these resources was reduced to a preambular affirmation that their conservation constitutes a common concern, again pointing towards additional funding arrangements at the international level. On the other hand, the funding from the North also failed to materialise to a level comparable to the significant importance attached to biodiversity.

\footnotetext{
34 For more information of the twists and turns of the negotiations see Fiona McConnell's very informative firsthand account of the negotiations, in which she participated as a member of the UK delegation; McConnell 1992 35 Report of the World Commission on Environment and Development, UNEP/GC Decision 14/4, (June 1987), UN Doc A/42/427 ('Brundtland Report')

36 Ibid., at 163

37 Hypothetically, this could have included such treaties such as the Ramsar Convention 1971, the World Heritage Convention 1972, CITES 1973 and the Bonn Convention 1979. The indicative list is borrowed from an assessment of major biodiversity-related treaties found in Veit Koester, 'The Five Global Biodiversity-Related Conventions: A Stocktaking' (2002) 11 Review of European Community and International Environmental Law 96 38 IUCN, UNEP and WWF, World Conservation Strategy: Living Resource Conservation for Sustainable Development (1980). ${ }_{39} \mathrm{CBD}$, Art. 3.
} 
Following the pattern of similar environmental negotiations on going at the time, these outcomes were quite often attributed to Southern interests. Conceptions of biodiversity as an economic opportunity and a way to make up lost development ground would be taken to infer an absence of commitment to environmental objectives or a push back against the benevolent 'greening' of international law.

However, if we connect these negotiating tactics and choices to the Malthusian leanings of the biodiversity concept, it becomes clear that at least equal responsibility for such an outcome (if indeed it is to be seen as contrary to certain environmental principles or goals) must be assigned to the rushed universalisation of a concept of biodiversity formulated with the relative narrow confines of North American academia and Northern environmental philosophy regarding the value of nature, and with little appreciation of the history of international law and international relations into which such a concept would be tapping. The creation of megabiodiverse states and the depiction of the human population in these states as a dangerous human mass might be more or less controversial depending on one's ecological understandings of the causes of a global environmental crisis; but such ideas do not make for smooth international diplomacy.

\section{MARKet ENVIRONMENTALISM AND THE CoMmercialization OF}

\section{BIODIVERSITY}

In the early years of the $\mathrm{CBD}$, the echo of a conservation framework treaty and the emergence of a complex political economy of biodiversity beyond conservation priorities produced contrarian reinterpretations of the goals of the CBD by Northern environmental thought that sought to protect international environmental law from encroachment from the Southern interests identified above. This was often identified through the reintroduction of aspects of the common heritage doctrine jettisoned from the main treaty text. Alan Boyle noted that the CBD 'represents an attempt... to internationalise, in a more comprehensive and inclusive way, the 
conservation and sustainable use of nature'40, lamenting how previous agreements 'fall short of establishing a comprehensive global regime for the protection of nature, and largely leave untouched resources located wholly within a state's own national boundaries'41. In similar vein, Swanson argued that the CBD was supposed to achieve 'the centralised management of global land use planning' ${ }^{2}$, and that it exists 'as a monument along the pathway of increasingly active intervention in the process of national development planning and decision-making' ${ }^{43}$. Such forms of internationalised and centralised intervention were simply incongruent with the NorthSouth dynamic at the inception of the CBD, notwithstanding the fact that the 1992 Rio Declaration on Environment and Development had imposed limits on state sovereignty over natural resources 44 .

In any event by that point in the early 1990s, the discourse was fully shifting away from conservation altogether and the North was once again instrumental in this shift. The above forms of intervention, with their costly reliance on implementation through global financial mechanisms and additional Northern funding commitments, were actually deemed unnecessary in the specific field of biodiversity. The answer to the question of how biodiversity conservation could be made possible without access to significant financial resources was to substitute sustainable utilisation for conservation. The outline of this plan was first worked on by a collaboration between the World Bank, IUCN and other leading environmental NGOs, which produced in 1990 the report titled Conserving the World's Biological Diversity 45 . The report's starting position, in line with sustainable development, was that 'the problems of conserving biological diversity $[\ldots]$ cannot be separated from the larger issues of social and economic development' 46 .

\footnotetext{
40 Alan E. Boyle, 'The Rio Convention on Biological Diversity' in Catherine Redgwell and Michael Bowman (eds), International Law and the Conservation of Biological Diversity (Kluwer Law International 1995), at 33.

41 Ibid

42 Timothy Swanson, 'Why is There a Biodiversity Convention? The International Interest in Centralized

Development Planning' (1999) 75 International Affairs 307 , at 308.

43 Ibid 307

44 Most directly through the wording of the second principle. See 31 ILM 874 (1992).

45 Jeffrey A. McNeely and others, Conserving the World's Biological Diversity (IUCN 1990)

$46 \mathrm{Ibid}$, at 11.
} 
For this endeavour to succeed biodiversity would have 'to compete for the attention of government and commercial decision-makers' 47 and 'to demonstrate in economic terms the contribution biological resources make to the countries' social and economic development48. In effect, the above approach decoupled the economic value of biodiversity from its environmental value as well as the North's willingness to pay for conservation, and instead firmly attached it to Southern developmental aspirations.

Michael Flitner commented in 1995 that 'if Wilson's book is the founding document of the biodiversity discourse, this is the basic policy paper of the global resource managers' 49 . Once state sovereignty and the lack of significant state funding from the North were established as parameters, other avenues of realising economic value from biodiversity were explored. The basic trajectories of the shift in priorities from conservation to management were enunciated: 'Enacting laws, closing access to resources and declaring additional protected areas' are characterised as 'defensive and often confrontational actions' 50 . Instead of polarisation, the report argued for 'cooperative efforts to address the social and economic foundations of resource depletion' ${ }_{51}$. It was further recognised that the partners in this new cooperative project are manifold: the national governments, development and environmental agencies, the nongovernmental sector, but also the 'marketplace' 52, the private sector, as well as local and indigenous communities.

In other words, state sovereignty over natural resources did not automatically mean public ownership of the lands where the biodiversity reserves were located or indeed of the biological resources themselves. That would be part of the defensive and confrontational actions that belonged to the old paradigm. In fact, it could mean quite the opposite. The creation of private

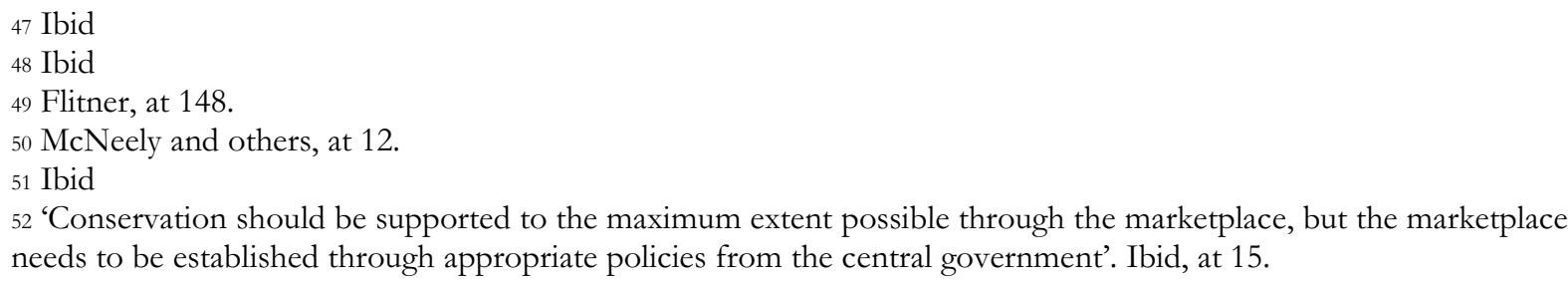
needs to be established through appropriate policies from the central government'. Ibid, at 15. 
markets and property rights would make sense as necessary components of biodiversity law and policy, in the sense of bringing in additional partners beyond the state. This was based on assumptions that private land ownership would be the best method to prevent overexploitation and degradation of specific habitats and that the economic potential of biodiversity would be such that a market could be created. These can all be traced back to Hardin's famous tragedy of the commons thesis 53, an attempt to counteract the Malthusian pressure of population on scarce resources through the establishment of private property rights.

In the early years after the entry into force of the CBD, one of the major Southern reactions in terms of making biodiversity 'pay its own way' 54 was a renewed belief that bioprospecting 55 , elevated to the level of 'another type of... very sophisticated agriculture' 56 , could provide such a market, producing a valuable - and commercially viable - genetic crop for the biotechnology industry and constituting a competitive form of land use that did not deplete biodiversity reserves or eradicate the crucial 'hotspots'. This would not necessarily privatise the ownership of lands within existing biodiversity hotspots, but would turn them into economic assets; any information and knowledge extracted from the samples collected would be turned into commodities for sale in a global market created by the biotech industry. The belief in the economic potential of biodiversity was ultimately what prompted the dominant conception of the CBD as a grand exchange that secures access for Northern industry and research to the South's biological resources57.

53 Garret Hardin, 'The Tragedy of the Commons' (1968) 162 Science 1243

54 For a trenchant critique of the application of market environmentalism to biodiversity see Kathleen McAfee, 'Selling Nature to Save it? Biodiversity and Green Developmentalism' (1999) 17 Environment and Planning D: Society and Space 133

55 I.e. the search for commercially viable plants, microorganisms, genes and biochemicals.

56 Rodrigo Gamez Lobo, at the time president of Costa Rica's newly created National Biodiversity Institute, quoted in Takacs, at 292.

57 Kerry ten Kate and Sarah A Laird, 'Biodiversity and Business: Coming to Terms with the 'Grand Bargain" (2000)

76 International Affairs 241 
The above extracts from the history of the North South dynamic have been chosen to illuminate a dominant repetitive pattern in thinking about biodiversity, which is simply that the North proposes and the South reacts and adapts. This is a worrying pattern, and has been criticised through the lens of orientalism:

'For green orientalists, as for their colonial forebears, all real knowledge, consciousness and power rest with the North. In environmental matters, as in others, they assume it is up to the North not only to explain, inspire and lead the South, but also to power it and teach it about itself 58.

In this sense, the revolving North-South dynamic that has fuelled the development of biodiversity law and policy has largely been unidirectional. Biodiversity problematisations emerge in the North and are adapted in the South. This phenomenon is doubly worrying because of the normative aspect of biodiversity, which has become inveigled with the very complex normative aspects of the project of development. The commitment to plural environmental values of conservation biology, organised under a biocentric holism, has in effect been overwhelmed by the many different values introduced through the rapid universalisation of biodiversity as a concept and globalisation of its application; to the point where the discourse is in a constant state of conflation between knowing and valuing nature and knowing and valuing human society outside the familiar refrains of the North.

58 Larry Lohmann, ‘Green Orientalism’ (1993) 23 The Ecologist 202, at 203. 


\section{Bibliography}

Barry J, Environment and Social Theory (2nd edn, Routledge 2007)

Boyle AE, 'The Rio Convention on Biological Diversity' in Redgwell C and Bowman M (eds), International Law and the Conservation of Biological Diversity (Kluwer Law International 1995)

Callicott JB, Crowder LB and Mumford K, 'Current Normative Concepts in Conservation' (1999) 13 Conservation Biology 22

Commoner B, The Closing Circle : Confronting the Environmental Crisis (Cape 1972)

Dryzek JS, The Politics of the Earth: Environmental Discourses (3rd edn, Oxford University Press 2013)

Ehrlich P, 'The Loss of Diversity: Causes and Consequences' in Wilson EO (ed), Biodiversity (National Academy Press 1988)

Ehrlich PR, The Population Bomb (Pan Books 1971)

Ehrlich PR, Ehrlich AH and Holdren JP, Ecoscience: Population, Resources, Environment (W.H. Freeman and Co 1972)

Farnham TJ, Saving Nature's Legacy : Origins of The Idea of Biological Diversity (Yale University Press 2007)

Flitner M, 'Biodiversity: Of Local Commons and Global Commodities' in Goldman M (ed), Privatizing Nature: Political Struggles for the Global Commons (Pluto Press 1998)

Hardin G, 'The Tragedy of the Commons’ (1968) 162 Science 1243

IUCN, UNEP and WWF, World Conservation Strategy: Living Resource Conservation for Sustainable Development (1980)

Koester V, 'The Five Global Biodiversity-Related Conventions: A Stocktaking' (2002) 11 Review of European Community and International Environmental Law 96 
Lautenschlager RA, 'Biodiversity is Dead' (1997) 25 Wildlife Society Bulletin 679

Lohmann L, ‘Green Orientalism’ (1993) 23 The Ecologist 202

Lovejoy TE, 'Biodiversity: What Is it?' in Reaka-Kudla ML, Wilson DE and Wilson EO (eds),

Biodiversity II: Understanding and Protecting Our Biological Resources (Joseph Henry Press 1996)

Malthus TR, An Essay on the Principle of Population and a Summary View of the Principle of Population (Penguin 1982)

McAfee K, 'Selling Nature to Save it? Biodiversity and Green Developmentalism' (1999) 17 Environment and Planning D: Society and Space 133

McNeely JA and others, Conserving the World's Biological Diversity (IUCN 1990)

Meadows DH and others, The Limits to Growth : a Report for the Club of Rome's Project on the Predicament of Mankind (Universe Books 1972)

Myers N and others, 'Biodiversity Hotspots’ (2000) 43 Nature 853

Najam A, 'Developing Countries and Global Environmental Governance: From Contestation to Participation to Engagement' (2005) 5 International Environmental Agreements 303

Nayar RJ and Ong DM, 'Developing Countries, 'Development' and the Conservation of Biological Diversity' in Redgwell C and Bowman M (eds), International Law and the Conservation of Biological Diversity (Kluwer Law International 1995)

Roebuck P and Phifer P, 'The Persistence of Positivism in Conservation Biology' (1999) 13 Conservation Biology 444

Sarkar S, Biodiversity and Environmental Philosophy: An Introduction (Cambridge University Press 2005)

Soule ME and Wilcox BA (eds), Conservation Biology: An Evolutionary-Ecological Perspective (Sinauer 1980)

Swanson T, 'Why is There a Biodiversity Convention? The International Interest in Centralized Development Planning' (1999) 75 International Affairs 307

Takacs D, The Idea of Biodiversity: Philosophies of Paradise (The John Hopkins University Press 1996) 
ten Kate K and Laird SA, 'Biodiversity and Business: Coming to Terms with the 'Grand Bargain' (2000) 76 International Affairs 241

Vogel JH, 'From the 'Tragedy of the Commons' to the 'Tragedy of the Commonplace': Analysis and Synthesis through the Lens of Economic Theory' in McManis CR (ed), Biodiversity and the Law : Intellectual Property, Biotechnology \& Traditional Knowledge (Earthscan 2007)

Vogt W, Road to survival (Gollancz 1949)

Wilson EO, 'The Current State of Biological Diversity' in Wilson EO (ed), BioDiversity (National Academy Press 1988)

—, The Diversity of Life (Penguin 2001)

— (ed), BioDiversity (National Academy Press 1988) 